\title{
The effect of the COVID-19 pandemic on domestic violence and child abuse
}

\author{
Sandra M. Bucerius, ${ }^{*}$ Brad W. R. Roberts, ${ }^{\star}$ and Daniel J. Jones ${ }^{\dagger}$
}

This article is related directly to the $6^{\text {th }}$ International Law Enforcement E Public Health (LEPH) Virtual Conference in March 2021.

\begin{abstract}
In response to the COVID-19 pandemic, many governments around the world have implemented lockdown or mass quarantine measures. While the purpose of these measures is to prevent the spread of the virus, they have had important social consequences. To determine the effect that pandemic-related isolation and quarantine measures have had on domestic violence and child abuse, we analyzed Canadian police calls for service data from 2015 to 2020. Our findings indicate that calls for service related to both domestic violence and child abuse have significantly increased during the pandemic. In light of these findings, we make recommendations for both government officials responsible for pandemic management and policing organizations on how to prevent increases in domestic violence and child abuse during future lockdowns.
\end{abstract}

Key Words Policing, quarantine, lockdown, abuse, children, violence.

\section{INTRODUCTION}

On 30 January 2020, the World Health Organization (WHO) declared the coronavirus disease 2019 (COVID-19) a Public Health Emergency of International Concern. Shortly thereafter, on 12 March 2020, the WHO declared COVID-19 a pandemic, and it rapidly became the largest global health emergency of the twenty-first century. In an attempt to stop the spread of the virus by preventing its human-to-human transmission, many governments around the world implemented (and still implement at the time of writing) "lockdown" or "mass quarantine" measures, which aim to limit the movement of people and prevent face-to-face interactions (Davies et al., 2020; Lau et al., 2020). Depending on the national, and sometimes local, context, some of these measures include work-from-home advisories, compulsory "shelter-in-place" orders, the closure of schools and non-essential services, as well as restrictions on social gatherings, travel, and border crossings (Wilder-Smith \& Freedman, 2020).

While such measures have shown to be effective in slowing the spread of the virus, preventing deaths, and alleviating stress on the healthcare system (Lau et al., 2020), they have other far-reaching consequences. On one hand, air quality has improved during the pandemic as a result of a reduction in greenhouse gas emissions (Zambrano-
Monserrate et al., 2020), due, in part, to significantly reduced air and road traffic in 2020. In particular, road traffic reduced by half globally in April 2020, while the number of air travel passengers reduced by 63\% in April 2020 in comparison with April 2019 (United Nations, 2020). On the other hand, previous studies have shown that mass quarantine measures and lockdowns both contribute to low life satisfaction, emotional isolation, and fear of infection (Cava et al., 2005; DiGiovanni et al., 2004; Reynolds et al., 2008; Zhang et al., 2020). The social and economic costs of social and physical distancing and lockdowns are particularly brutal for the most vulnerable members of society. These individuals are typically engaged in employment where they are less likely to be able to work from home and experience higher rates of unemployment due to the closure of non-essential services (International Labour Organization, 2020). Furthermore, some essential services for vulnerable populations (e.g., homeless shelters) have been forced to close to mitigate the spread of the virus (Perri et al., 2020). When focusing on youth, research on the effect of quarantine measures and isolation on children has shown a higher likelihood of developing acute stress disorder, adjustment disorder, and grief, with $30 \%$ of quarantined or isolated children meeting clinical criteria for posttraumatic stress disorder (Sprang \& Silman, 2013). Nationwide school closures could also negatively impact the health and

Correspondence to: Sandra Bucerius, Department of Sociology, University of Alberta, Tory 6-20, Edmonton, AB T6G 2H4, Canada. E-mail: Bucerius@ualberta.ca.

To cite: Bucerius, S. M., Roberts, B. W. R., and Jones, D. J. (2021). The Effect of the COVID-19 Pandemic on Domestic Violence and Child Abuse. Journal of Community Safety and Well-Being, 6(2), 75-79. https://doi.org.10.35502/jcswb.204

@ Author(s) 2021. Open Access. This work is distributed under the Creative Commons BY-NC-ND license. For commercial re-use, please contact sales@sgpublishing.ca. SPUBLISHING Published by SG Publishing Inc. CSRA Official publication of the Community Safety Knowledge Alliance. 
well-being of children, since evidence suggests that children are less physically active, have significantly longer screen time, irregular sleep patterns, and less favourable diets when not participating in school (Brazendale et al., 2017).

The various societal costs of the pandemic will need to be carefully studied over time and across different research disciplines to understand its impact on public health, life satisfaction, mental health, the psychological as well as social development of children, and educational outcomes. The role of criminologists will be to study the effect of the pandemic on crime rates. Historically, criminologists have observed an increase in violence and drug use during times of recession and economic crisis (Carpenter, 2017; Dávalos et al., 2011; Hollingsworth et al., 2017; Schneider et al., 2016), as well as an increase in domestic violence following disasters (see, for example, Rahman, 2013, and Gearhart et al., 2018). In this light, we hypothesize that the COVID-19 pandemic and its associated government-mandated lockdowns have had a similar effect on such crime rates. By analyzing Canadian data, our article will provide some initial insights into the effect of the COVID-19 pandemic on both domestic violence and child abuse. The research question we will address is the following: What effect do quarantine measures and isolation have on the calls for service to police organizations pertaining to domestic violence and child abuse? We make specific recommendations for policing organizations that follow from our findings.

\section{CONTEXT}

\section{Domestic Violence and Child Abuse}

A number of scholars have historically examined the impact of pandemics, disasters, and other major crises on domestic violence. For example, Decker et al. (2013) examined how the HIV pandemic influenced the abuse of women, whereas Wilson et al. (1998), Gearhart et al. (2018), and Parkinson (2019) examined the increase of domestic violence following disasters. Several scholars have commented on the effect of social isolation during the COVID-19 pandemic on domestic violence around the world (van Gelder et al., 2020). In particular, there has been a 40\%-50\% increase in domestic violence in Brazil (Graham-Harrison et al., 2020); there was a 20\%-30\% increase in calls to domestic violence helplines in Cyprus and Spain in the several days following implementation of their government-mandated isolation measures; there has been a surge in calls to the National Domestic Violence Hotline in the United States since the beginning of the pandemic (Thomas, 2020); and there was a $25 \%$ increase in calls related to domestic violence in the United Kingdom within just one week of implementation of their lockdown measures (BBC, 2020). Scholars have additionally begun examining contextual differences in the rise of domestic violence. For example, Boserup et al. (2020) demonstrated significant differences in domestic violence increases between different states in the United States, with a range between $10 \%$ and $27 \%$ in March 2020 in comparison with March 2019. Just recently, a meta-analysis by Piquero et al. (2021) found that, across the 18 included studies, officially reported domestic violence increased by an average of 7.9\% during the COVID-19 pandemic internationally, with a slightly higher average $(8.1 \%)$ increase across studies performed in the United States.
In contrast to research on the effect of pandemics or other disasters on domestic violence, there has been comparatively less empirical research examining the relation between such events and child abuse. However, it is well established that stress can cause cognitive, emotional, and physical fatigue, all of which can strain relationships between children and their parents (Deater-Deckard, 2004). The consequences of this often include harsher parenting (Beckerman et al., 2014) and child abuse (Rodriguez-Jenkins \& Marcenko, 2014). Stress is, therefore, an important factor to consider when examining the consequences of the COVID-19 pandemic. Lockdowns, the closure of schools and non-essential services, physical distancing measures, and the indefinite loss of employment have resulted in many individuals and families experiencing stressful economic situations as well as heightened mental health concerns (e.g., Marazziti et al., 2020; Brown et al., 2020).

\section{Research Location}

COVID-19 was first detected in Alberta, Canada, in January 2020 and was traced to out-of-country travel. By 5 March 2020, the province was experiencing exponential growth in transmission of the virus, and by 15 March 2020, all schools across the province were closed. On 16 March 2020, Edmonton, Alberta, where our research takes place, closed all city-run facilities (e.g., libraries, gyms, and hockey arenas), cancelled all international flights to and from the city, and allowed only essential services to remain open. Edmonton is the capital of Alberta and the most populous northern city in the world, with close to one million residents within city limits and approximately 400,000 additional residents in neighboring communities. The city has a police service (Edmonton Police Service (EPS)) with approximately 2,500 members, 1,800 of whom are sworn police officers. In the initial phases of the lockdown (i.e., following 15 March 2020), the EPS experienced a decrease in the frequency of calls for service. This decrease could largely be explained by the fact that many individuals were working from home, resulting in a decrease in the frequency of residential break and enters and fewer traffic accidents. Shortly after 15 March 2020, however, commercial break and enters began to increase (with non-essential services being closed, the reporting of such break and enters was delayed). The other types of crime for which the EPS received increased calls for service include domestic violence and child abuse.

\section{METHODS}

We entered into a research agreement with the EPS, and they provided us with Edmonton calls-for-service data for two types of crime, domestic violence and child abuse, between the years 2015 and 2020. The dataset contained only calls for service that resulted in a charge in one of the two described categories. In other words, calls for service that did not result in a charge, or resulted in a charge for a different type of crime, were not included in the dataset. Using these data, we tabulated the number of occurrences of domestic violence and child abuse in each yearly quarter from the beginning of 2015 to the end of 2020. We also calculated the average number of occurrences for 2015 through 2019, and, for each type of crime, the percent change in occurrences from the 2015-2019 average to 2020 for each quarter. 


\section{RESULTS}

In Figure 1, the total number of domestic violence (Figure 1A) and child abuse (Figure 1B) occurrences are shown from the beginning of 2015 to the end of 2020. A visual inspection suggests that the number of domestic violence and child abuse occurrences were both greater in 2020 than in the previous years shown.

In Table I, the average number of domestic violence and child abuse occurrences between 2015 and 2019 are shown for each yearly quarter. The number of occurrences in 2020, as well as the percent change from the 2015-2019 average to this year, are also shown. For both types of crime and all yearly quarters, there was a significant increase in occurrences from 2015-2019 to 2020 (e.g., there was a 54\% increase in child abuse in 2020 compared with 2015-2019 for the third yearly quarter). These results confirm the visual inspection of Figure 1.

\section{DISCUSSION}

The potential long-term consequences of COVID-19 on public health are currently not well understood. However, while a focus on the impact of the disease on public health is important, attention must also be paid to the wider societal costs of the pandemic and its associated lockdowns. Our findings draw attention to the consequences on two types of crime during a state-ordered lockdown: domestic violence and child

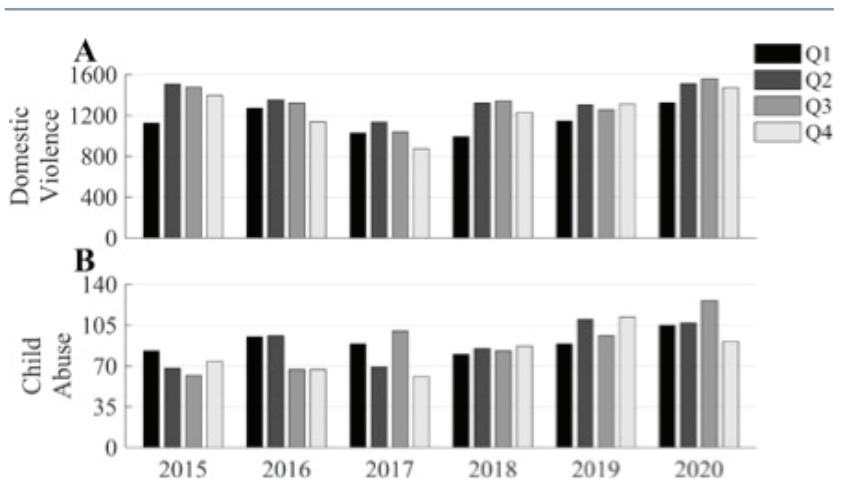

FIGURE 1 Domestic violence $(A)$ and child abuse $(B)$ occurrences in Edmonton, $A B, C A$ between the years 2015 and 2020. Shown are the total number of occurrences in the first $(Q 1)$, second $(Q 2)$, third $(Q 3)$, and fourth (Q4) yearly quarters from the beginning of 2015 to the end of 2020.

TABLE 1 Average number of domestic violence and child abuse occurrences in Edmonton, $A B, C A$ between the years 2015 and 2019 as well as the percent change in occurrences from the 2015-2019 average to 2020 .

\begin{tabular}{ccccccc}
\hline & \multicolumn{3}{c}{ Domestic Violence } & \multicolumn{3}{c}{ Child Abuse } \\
\hline Quarter & $\begin{array}{c}2015-2019 \\
\text { Average }\end{array}$ & 2020 & Change & $\begin{array}{c}\text { 2015-2019 } \\
\text { Average }\end{array}$ & 2020 & Change \\
\hline 1 & 1,111 & 1,325 & $19 \%$ & 87 & 105 & $20 \%$ \\
2 & 1,324 & 1,511 & $14 \%$ & 86 & 107 & $25 \%$ \\
3 & 1,286 & 1,559 & $21 \%$ & 82 & 126 & $54 \%$ \\
4 & 1,190 & 1,472 & $24 \%$ & 80 & 91 & $13 \%$ \\
\hline
\end{tabular}

abuse. Calls for service for both types of crime have significantly increased during the pandemic. These findings have implications for future lockdowns and, in particular, raise the question of how policing organizations can potentially address anticipated lockdown-related issues before they arise. In light of our findings, we make recommendations for both government officials responsible for pandemic management and policing organizations:

As our findings indicate, domestic violence and child abuse both increase during lockdowns. With this knowledge, policing organizations should be prepared to pivot during times of lockdown, moving resources to their units responsible for domestic violence and child abuse.

- Our data shed light on the unintended consequences of school closures, especially pertaining to children in elementary school (i.e., kindergarten to sixth grade). In addition to its educational role, school often serves as a safe place for children, sometimes the only safe place they have. With this in mind, the closure of schools may have two detrimental effects on child abuse: (1) children lose their safe space and access to adults they may be able to trust (including a school resource officer that they may have a trusting relationship with); and (2) perpetrators in the home have continued access to their victims, while also not needing to fear that the children in their care will report their victimization to teachers, school social workers, school resource officers, school friends, or friends' parents. To prevent child abuse, school closures should therefore always be a last resort. If schools must close, we recommend that schools and teachers develop best practices to identify students who are at an increased risk of child abuse during school closure and develop protocols for how to routinely check in with such students and their families. This could potentially be realized in collaboration with school resource officers.

- More broadly, the empirical evidence of significant increases in both domestic violence and child abuse further highlights the need for trauma awareness for first responders, in general, and police officers, specifically (Jones 2020). The longitudinal impact of domestic violence and child abuse as they relate to Adverse Childhood Experiences (ACEs) is well documented (Merrick et al., 2017; Messina \& Grella, 2016; Finkelhor et al., 2015). Consequently, trauma awareness and trauma-informed programming, as well as educating police officers and justice workers about the impact of domestic violence and childhood abuse, are critical. Such training is particularly important during disasters and pandemics, as police officers must respond to increased calls for service for crimes related to domestic violence and child abuse.

- During economic downturns, funds for prevention of, and social intervention in, social issues are often reduced. Since the economy of Alberta has been devastated by the pandemic, we are therefore concerned that programs to prevent domestic violence and child abuse will be among those that receive less funding. Given the long-term impact of domestic violence and child abuse, we urge the government to reconsider such potential funding 
cuts. Without the described programs, the police will likely deal with an increase in cases related to domestic violence and child abuse.

- There needs to be increased media attention on domestic violence and child abuse, especially during times of statemandated lockdowns, when regular safe spaces may not be available for victims. Victims need to know who they can call and reach out to when being victimized, and the public needs to understand warning signs that may urge them to call the police. This could be accomplished via media campaigns involving police officials.

- In many jurisdictions, victim-centered services closed their operations, preventing victims of domestic violence or child abuse from physically meeting with victim service workers. Future research should investigate whether this has affected the use of these services. If the use of such services has decreased, police organizations need to determine how to safely administer physical programming during future lockdowns.

- There is promising research on how focused deterrence can reduce domestic violence (Sechrist \& Weil, 2018). Policing organizations could benefit from investigating evidence-based practices on focused deterrence and consulting with experts on how focused deterrence could be implemented during future lockdowns.

While our data show an increase in calls for service in Edmonton for both domestic violence and child abuse during the pandemic, further research is needed to determine whether our results apply to other populations. Since Edmonton is a blue-collar city in a province that is predominately dependent on the petroleum industry - which has experienced a downward trend during the pandemic-it is possible that our findings are influenced by the fact that many Albertan families have experienced elevated stress during the pandemic caused by severe economic struggles. As discussed, previous research has shown that stress plays an important factor in relationships and well-being and could be an indirect cause of the observed increase in domestic violence and child abuse. It is possible that calls for service related to domestic violence and child abuse did not increase to the same extent in areas that were not negatively affected economically to the same extent as Alberta.

Our findings raise awareness of the societal costs of government-initiated lockdowns and pandemic management while also providing recommendations for police organizations.

\section{CONFLICT OF INTEREST DISCLOSURES}

The author has no conflicts of interest to declare.

\section{AUTHOR AFFILIATIONS}

${ }^{*}$ University of Alberta, Edmonton, $\mathrm{AB} ;{ }^{+}$Huddersfield University, Huddersfield, United Kingdom/Edmonton Police Service, Edmonton, AB.

\section{REFERENCES}

BBC. (2020). Coronavirus: Domestic abuse calls up 25\% since lockdown, charity says. https://www.bbc.co.uk/news/uk-52157620

Beckerman, M., van Berkel, S. R., Mesman, J., \& Alink, L. R. A. (2017).

The role of negative parental attributions in the associations between daily stressors, maltreatment history, and harsh and abusive discipline. Child Abuse \& Neglect, 64, 109-116.

Boserup, B., McKenney, M., \& Elkbuli, A. (2020). Alarming trends in US domestic violence during the COVID-19 pandemic. American Journal of Emergency Medicine, 38(12), 2753-2755.

Brazendale, K., Beets, M. W., Weaver, R. G., Pate, R. R., Turner-McGrievy, G. M., Kaczynski, A. T., Chandler, J. L., Bohnert, A., \& von Hippel, P. T. (2017). Understanding differences between summer vs. school obesogenic behaviors of children: the structured days hypothesis. International Journal of Behavioral Nutrition and Physical Activity, $14,100$.

Brown, S., Doom, J., Lechuga-Peña, S., Enos Watamura, S., \& Koppels, T. (2020). Stress and parenting during the global COVID-19 pandemic. Child Abuse \& Neglect, 110(2).

Cava, M. A., Fay, K. E., Beanlands, H. J., McCay, E. A., \& Wignall, R. (2005). The experience of quarantine for individuals affected by SARS in Toronto. Public Health Nursing, 22, 398-406.

Carpenter, C. S., McClellan, C. B., \& Rees, D. I. (2017). Economic conditions, illicit drug use, and substance use disorders in the United States. Journal of Health Economics, 52, 63-73.

Dávalos, M. E., Fang, H., \& French, M. T. (2011). Easing the pain of an economic downturn: Macroeconomic conditions and excessive alcohol consumption. Health Economics, 21(11), 1318-1335.

Davies, N. G., Kucharski, A. J., Eggo, R. M., Gimma, A., Edmunds, W. J., Jombart, T., O'Reilly, K., Endo, A., Hellewell, J., Nightingale, E. S., Quilty, B. J., Jarvis, C. I., Russell, T. W., Klepac, P., Bosse, N. I., Funk, S., Abbott, S., Medley, G. F., Gibbs, H., Pearson, C. A. B., ... Liu, Y. (2020). The effect of non-pharmaceutical interventions on COVID-19 cases, deaths and demand for hospital services in the UK: A modelling study. Lancet Public Health, 5, 375-385.

Deater-Deckard, K. (2004). Parenting stress. Yale University Press.

Decker, M. R., Wirtz, A. L., Pretorius, C., Sherman, S. G., Sweat, M. D., Baral, S. D., Byrer, C., \& Kerrigan, D. L. (2013). Estimating the impact of reducing violence against female sex workers on HIV epidemics in Kenya and Ukraine: A policy modeling exercise. American Journal of Reproductive Immunology, 69, 122-132.

DiGiovanni, C., Conley, J., Chiu, D., \& Zaborski, J. (2004). Factors influencing compliance with quarantine in Toronto during the 2003 SARS outbreak. Biosecurity and Bioterrorism: Biodefense Strategy, Practice, and Science, 2, 265-272.

Finkelhor, D., Turner, H. A., Shattuck, A., \& Hamby, S. L. (2015). Prevalence of childhood exposure to violence, crime, and abuse: Results from the national survey of children's exposure to violence. JAMA Pediatrics, 169(8), 746-754.

Gearhart, S., Perez-Patron, M., Hammond, T. A., Goldberg, D. W., Klein, A., \& Horney, J. A. (2018). The impact of natural disasters on domestic violence: An analysis of reports of simple assault in Florida (1999-2007). Violence and Gender, 5(2), 87-92.

Graham-Harrison, E., Giuffrida, A., Smith, H., \& Ford, L. (2020, March 28). Lockdowns around the world bring rise in domestic violence. The Guardian. https://www.theguardian.com/society/2020/ mar/28/lockdowns-world-rise-domestic-violence?CMP=Share_ iOSApp_Other

Hollingsworth, A., Ruhm, C. J., \& Simon, K. (2017). Macroeconomic conditions and opioid abuse. Journal of Health Economics, 56, 222-233.

International Labour Organization. (2020). In the face of a pandemic: Ensuring safety and health at work. Geneva: ILO. https://www.ilo. org/wcmsp5/groups/public/---ed_protect/---protrav/---safework/ documents/publication/wcms_742463.pdf

Jones, D. J. (2020). Pandemic policing: Highlighting the need for traumainformed services during and beyond the COVID-19 crisis. Journal of Community Safety and Well-Being, 5(2), 69-72. 
EFFECTS OF COVID-19 ON DOMESTIC VIOLENCE, Bucerius et al.

Lau, H., Khosrawipour, V., Kocbach, P., Mikolajczyk, A., Schubert, J., Bania, J., \& Khosrawipour, T. (2020). The positive impact of lockdown in Wuhan on containing the COVID-19 outbreak in China. Journal of Travel Medicine, 27(3), 1-7.

Marazziti, D., Pozza, A., Giuseppe, M. D., \& Conversano, C. (2020). The psychological impact of COVID-19 pandemic in Italy: A lesson for mental health prevention in the first severely hit European city. Psychological Trauma Theory Research Practice and Policy, 12 (51, 531-533.

Merrick, M. T., Ports, K. A., Ford, D. C., Afifi, T. O., Gershoff, E. T., \& Grogan-Kaylor, A. (2017). Unpacking the impact of adverse childhood experiences on adult mental health. Child Abuse \& Neglect, $69,10-19$.

Messina, N., \& Grella, C. (2006). Childhood trauma and women's health outcomes in a California prison population. American Journal of Public Health, 96(10), 1842-1848.

Parkinson, D. (2019). Investigating the increase in domestic violence post disaster: An Australian case study. Journal of Interpersonal Violence, 34(11), 2333-2362.

Perri, M., Dosani, N., \& Hwang, S. W. (2020). COVID-19 and people experiencing homelessness: Challenges and mitigation strategies. Canadian Medical Association Journal, 192(26), E716-E719.

Piquero, A. R., Jennings, W. G., Jemison, E., Kaukinen, C., \& Knaul, F. M. (2021, March). Domestic violence during COVID-19: Evidence from a systematic review and meta-analysis. Washington, DC: Council on Criminal Justice.

Rahman, M. S. (2013). Climate change, disaster and gender vulnerability: A study on two divisions of Bangladesh. American Journal of Human Ecology, 2(2), 72-82.

Reynolds, D. L, Garay, J. R., Deamond, S. L., Moran, M. K., Gold, W. \& Styra, R. (2008). Understanding, compliance and psychological impact of the SARS quarantine experience. Epidemiology \& Infection, 136, 997-1007.

Rodriguez-Jenkins, J., \& Marcenko, M. О. (2014). Parenting stress among child welfare involved families: Differences by child placement. Children and Youth Services Review, 46, 19-24.
Schneider, D., Harknett, K., \& McLanahan, S. (2016). Intimate partner violence in the great recession. Demography, 53(2), 471-505.

Sechrist, S. M., \& Weil, J. D. (2018). Assessing the impact of a focused deterrence strategy to combat intimate partner domestic violence. Violence Against Women, 24(3), 243-265.

Sprang, G., \& Silman, M. (2013). Posttraumatic stress disorder in parents and youth after health-related disasters. Disaster Medicine and Public Health Preparedness, 7, 105-110.

Thomas, J. Domestic violence calls increase locally, nationwide during COVID-19 pandemic. Kalb. https://www.kalb.com/content/news/ Domestic-violence-calls-increase-locally-nationwide-during-COVID19-pandemic\%2D\%2D569689371.html

United Nations. (2020). Shared responsibility, global solidarity: Responding to the socio-economic impacts of COVID-19. United Nations, 2020. https://unsdg.un.org/sites/default/files/2020-03/SGReport-Socio-Economic-Impact-of-Covid19.pdf.

van Gelder, N., Peterman, A., Potts, A., O'Donnell, M., Thompson, K., Shah, N., \& Oertelt-Prigione, S. (2020). COVID-19: Reducing the risk of infection might increase the risk of intimate partner violence. EClinicalMedicine. https://doi.org/10.1016/i.eclinm.2020.100348

Wilder-Smith, A., \& Freedman, D. O. (2020). Isolation, quarantine, social distancing and community containment: Pivotal role for old-style public health measures in the novel coronavirus (2019-nCoV) outbreak. Journal of Travel Medicine, 27, 1-4.

Wilson, J., Phillips, B., \& Neal, D. M. (1998). Domestic violence after disaster. In E. Enarson \& B. H. Morrow (Eds.), The gendered terrain of disaster: Through women's eyes (pp. 115-123). Praeger.

Zambrano-Monserrate, M. A., Ruano, M. A., \& Sanchez-Alcalde, L. (2020). Indirect effects of COVID-19 on the environment. Science of The Total Environment, 728, 1-4.

Zhang, S. X., Wang, Y., Rauch, A., \& Wei, F. (2020). Unprecedented disruption of lives and work: Health, distress and life satisfaction of working adults in China one month into the COVID-19 outbreak. Psychiatry Research, 288, 112958. 